\title{
Jeotgalibacillus salarius sp. nov., isolated from a marine saltern, and reclassification of Marinibacillus marinus and Marinibacillus campisalis as Jeotgalibacillus marinus comb. nov. and Jeotgalibacillus campisalis comb. nov., respectively
}

Correspondence Jung-Hoon Yoon jhyoon@kribb.re.kr

\author{
Jung-Hoon Yoon, ${ }^{1}$ So-Jung Kang, ${ }^{1}$ Peter Schumann ${ }^{2}$ \\ and Tae-Kwang $\mathrm{Oh}^{1}$
}
${ }^{1}$ Korea Research Institute of Bioscience and Biotechnology (KRIBB), PO Box 115, Yusong, Taejon, Republic of Korea
${ }^{2}$ DSMZ-Deutsche Sammlung von Mikroorganismen und Zellkulturen GmbH, Mascheroder Weg 1B, D-38124 Braunschweig, Germany

The genus Jeotgalibacillus was created by Yoon et al. (2001b) with the description of Jeotgalibacillus alimentarius as the sole recognized species of the genus. The genus Jeotgalibacillus is characterized chemotaxonomically by having cell-wall peptidoglycan based on L-lysine as the diamino acid, MK-7 and MK-8 as the predominant menaquinones and major amounts of the fatty acid iso$\mathrm{C}_{15: 0}$. J. alimentarius was isolated from a Korean traditional fermented seafood, jeotgal. The genus Jeotgalibacillus is most phylogenetically closely related to the genus Marinibacillus (Yoon et al., 2001b, 2004). The genus Marinibacillus was proposed by Yoon et al. (2001b) by the reclassification of

The GenBank/EMBL/DDBJ accession number for the 16S rRNA gene sequence of strain $\mathrm{ASL}-1^{\top}$ is EU874389.
Bacillus marinus (Rüger \& Richter, 1979; Rüger, 1983) and subsequently, another species, Marinibacillus campisalis (Yoon et al., 2004), was described. Members of the genus Marinibacillus have cell-wall peptidoglycan based on L-lysine as the diamino acid, MK-7 as the predominant menaquinone and anteiso- $\mathrm{C}_{15: 0}$ as the predominant fatty acid (Yoon et al., 2001b, 2004). In this study, we describe a bacterial strain, ASL- $1^{\mathrm{T}}$, which was isolated from a marine saltern in Korea. This isolate was phylogenetically related to the genera Jeotgalibacillus and Marinibacillus on the basis of 16S rRNA gene sequence comparisons. The aim of the present work was to determine the exact taxonomic position of strain ASL $-1^{\mathrm{T}}$ by using a polyphasic characterization and to reevaluate the taxonomic status of the genera Jeotgalibacillus and Marinibacillus. 
Strain ASL- ${ }^{\mathrm{T}}$ was isolated by means of the standard dilution plating technique at $30{ }^{\circ} \mathrm{C}$ on marine agar 2216 (MA; Difco) supplemented with $8 \%(\mathrm{w} / \mathrm{v}) \mathrm{NaCl}$. J. alimentarius YKJ-13 ${ }^{\mathrm{T}}$, Marinibacillus marinus DSM $1297^{\mathrm{T}}$ and M. campisalis SF- $57^{\mathrm{T}}$ were used as reference strains for DNA-DNA hybridization and/or phenotypic characterization. The morphological, physiological and biochemical characteristics of strain ASL- $1^{\mathrm{T}}$ were investigated using routine cultivation on $\mathrm{MA}$ at $30{ }^{\circ} \mathrm{C}$. Cell morphology was examined by using light microscopy (E600; Nikon) and transmission electron microscopy. Flagellation was determined using a Philips CM-20 transmission electron microscope with cells from exponentially growing cultures. For this purpose, the cells were negatively stained with $1 \%(\mathrm{w} / \mathrm{v})$ phosphotungstic acid and the grids were examined after being air-dried. Growth under anaerobic conditions was determined after incubation in a Forma anaerobic chamber on MA and on MA supplemented with potassium nitrate $(0.1 \%, \mathrm{w} / \mathrm{v})$, both of which had been prepared anaerobically under a nitrogen atmosphere. The $\mathrm{pH}$ range for growth was determined in marine broth 2216 (MB; Difco), adjusted to various $\mathrm{pH}$ values ( $\mathrm{pH} 4.5-9.5$, at intervals of $0.5 \mathrm{pH}$ units) by the addition of $\mathrm{HCl}$ or $\mathrm{Na}_{2} \mathrm{CO}_{3}$. Growth in the absence of $\mathrm{NaCl}$ was investigated using trypticase soy broth prepared according to the formula of the Difco medium except that $\mathrm{NaCl}$ was excluded. Growth in the absence of $\mathrm{NaCl}$ and in the presence of $0.5,1.0,2.0$ and $3.0 \%(\mathrm{w} / \mathrm{v}) \mathrm{NaCl}$ was investigated by using trypticase soy broth, using supplementation with $0.45 \%(\mathrm{w} / \mathrm{v}) \mathrm{MgCl}_{2} \cdot 6 \mathrm{H}_{2} \mathrm{O}$ or $0.06 \%(\mathrm{w} / \mathrm{v})$ $\mathrm{KCl}$, prepared according to the formula of the Difco medium except that $\mathrm{NaCl}$ was excluded. Growth at various $\mathrm{NaCl}$ concentrations $(2.0-20.0 \%, \mathrm{w} / \mathrm{v}$, at increments of $1.0 \%$ ) was investigated in MB. Growth at various temperatures $(4,10,15,20,25,28,30,35,37,40$ and $45^{\circ} \mathrm{C}$ ) was measured on MA. Catalase and oxidase activities and hydrolysis of casein, starch and Tweens 20, 40, 60 and 80 were determined as described by Cowan \& Steel (1965). Hydrolysis of hypoxanthine, tyrosine and xanthine was tested on MA using the substrate concentrations described by Cowan \& Steel (1965). Hydrolysis of aesculin, gelatin and urea and nitrate reduction were investigated as described previously (Lányí, 1987) with the modification that artificial seawater was used for the preparation of media. The artificial seawater contained ( $1^{-1}$ distilled water): $23.6 \mathrm{~g} \mathrm{NaCl}, 0.64 \mathrm{~g} \mathrm{KCl}, 4.53 \mathrm{~g}$ $\mathrm{MgCl}_{2} \cdot 6 \mathrm{H}_{2} \mathrm{O}$, $5.94 \mathrm{~g} \quad \mathrm{MgSO}_{4} \cdot 7 \mathrm{H}_{2} \mathrm{O}$ and $1.3 \mathrm{~g}$ $\mathrm{CaCl}_{2} \cdot 2 \mathrm{H}_{2} \mathrm{O}$ (Bruns et al., 2001). $\mathrm{H}_{2} \mathrm{~S}$ production was tested as described previously (Bruns et al., 2001). Susceptibility to antibiotics was investigated on MA plates by using antibiotic discs with the following concentrations: polymyxin B $(100 \mathrm{U})$, streptomycin $(50 \mu \mathrm{g})$, penicillin $\mathrm{G}$ (20 U), chloramphenicol $(100 \mu \mathrm{g})$, ampicillin $(10 \mu \mathrm{g})$, cephalothin $(30 \mu \mathrm{g})$, gentamicin $(30 \mu \mathrm{g})$, novobiocin $(5 \mu \mathrm{g})$, tetracycline $(30 \mu \mathrm{g})$, kanamycin $(30 \mu \mathrm{g})$, lincomycin $(15 \mu \mathrm{g})$, oleandomycin $(15 \mu \mathrm{g})$, neomycin $(30 \mu \mathrm{g})$ and carbenicillin $(100 \mu \mathrm{g})$. Acid production from carbohydrates was tested as described by Leifson (1963). Enzyme activities were determined by using the API ZYM system (bioMérieux) with the modification that the cells used to inoculate the API ZYM strip were suspended in artificial seawater and the strip was incubated for $8 \mathrm{~h}$.

Cell biomass for DNA extraction and for the analyses of cell-wall peptidoglycan and isoprenoid quinones was obtained from cultures grown in $\mathrm{MB}$ at $30{ }^{\circ} \mathrm{C}$. Chromosomal DNA was isolated and purified according to the method described by Yoon et al. (1996), with the exception that RNase T1 was used in combination with RNase A to minimize the contamination of RNA. The 16S rRNA gene was amplified by PCR using two universal primers, 5'-GAGTTTGATCCTGGCTCAG-3' and $5^{\prime}$ AGAAAGGAGGTGATCCAGCC- ${ }^{\prime}$, as described previously (Yoon et al., 1998). Sequencing of the amplified $16 \mathrm{~S}$ rRNA gene and phylogenetic analysis were performed as described by Yoon et al. (2003). Preparation of cell walls and determination of peptidoglycan structure were carried out by using methods described by Schleifer \& Kandler (1972), MacKenzie (1987) and Groth et al. (1996). Isoprenoid quinones were analysed as described by Komagata \& Suzuki (1987) using reversed-phase HPLC and a YMC ODS-A $(250 \times 4.6 \mathrm{~mm})$ column. For cellular fatty acid analysis, cell mass of strain ASL- $1^{\mathrm{T}}$ and J. alimentarius $\mathrm{YKJ}-13^{\mathrm{T}}$ was harvested from MA plates after cultivation for 3 days at $30{ }^{\circ} \mathrm{C}$. The fatty acids were extracted and fatty acid methyl esters were prepared according to the standard protocol of the MIDI/Hewlett Packard Microbial Identification System (Sasser, 1990). The DNA G $+\mathrm{C}$ content was determined by using the method of Tamaoka \& Komagata (1984) with the modification that DNA was hydrolysed using nuclease P1 (Sigma) and the resultant nucleotides were analysed by using reversed-phase HPLC. DNA-DNA hybridization was performed fluorometrically using the method of Ezaki et al. (1989) with photobiotin-labelled DNA probes and microdilution wells. Hybridization was performed with five replications for each sample. The highest and lowest values obtained in each sample were excluded, and the means of the remaining three values were quoted as DNA-DNA relatedness values.

Morphological, cultural, physiological and biochemical characteristics of strain ASL- ${ }^{\mathrm{T}}$ are given in the species description (see below) or are shown in Table 1. The almost-complete $16 \mathrm{~S}$ rRNA gene sequence of strain ASL-1 ${ }^{\mathrm{T}}$ determined in this study comprised $1507 \mathrm{nt}$, representing approximately $96 \%$ of the Escherichia coli $16 \mathrm{~S}$ rRNA gene sequence. In the phylogenetic tree based on the neighbourjoining algorithm, strain ASL- $1^{\mathrm{T}}$ clustered with J. alimentarius YKJ-13 ${ }^{\mathrm{T}}$ with a bootstrap resampling value of $95.1 \%$, and this cluster joined the clade comprising two Marinibacillus species with a bootstrap resampling value of $99.5 \%$ (Fig. 1). The same topology was also found in the trees constructed using the maximum-likelihood and maximum-parsimony algorithms (Fig. 1). Strain ASL- $1^{\mathrm{T}}$ exhibited a $16 \mathrm{~S}$ rRNA gene sequence similarity value of $97.3 \%$ to J. alimentarius $\mathrm{YKJ}-13^{\mathrm{T}}$ and relatively high 
Table 1. Differential phenotypic characteristics of Jeotgalibacillus salarius and the type strains of Jeotgalibacillus and Marinibacillus species

Species: 1, J. salarius sp. nov.; 2, J. alimentarius (data from Yoon et al., 2001b and this study); 3, M. marinus (Rüger, 1983; Yoon et al., 2001b; this study); 4, M. campisalis (Yoon et al., 2004; this study). +, Positive reaction; -, negative reaction; w, weakly positive reaction; v, variable reaction; ND, not determined. All species were rod-shaped and positive for motility, catalase, hydrolysis of aesculin and casein, acid production from Dfructose, D-glucose, maltose, sucrose and trehalose, and susceptibility to carbenicillin, cephalothin, chloramphenicol, gentamicin, neomycin, oleandomycin and penicillin G. All species were negative for hydrolysis of hypoxanthine, xanthine, tyrosine and urea, and acid production from Larabinose, lactose, L-rhamnose, myo-inositol and D-sorbitol, susceptibility to polymyxin B, and activity of alkaline phosphatase, lipase (C14), leucine arylamidase, valine arylamidase, cystine arylamidase, trypsin, $\alpha$-chymotrypsin, acid phosphatase, $\alpha$-galactosidase, $\beta$-glucuronidase, $\beta$ glucosidase, $N$-acetyl- $\beta$-glucosaminidase, $\alpha$-mannosidase and $\alpha$-fucosidase.

\begin{tabular}{|c|c|c|c|c|}
\hline Characteristic & 1 & 2 & 3 & 4 \\
\hline Spore shape & Ellipsoidal & Round & Round or slightly ellipsoidal & Round or ellipsoidal \\
\hline Spore position & Subterminal & Terminal or subterminal & Terminal or subterminal & Terminal or subterminal \\
\hline Flagella type & Peritrichous & Peritrichous & Peritrichous & Single polar \\
\hline Gram staining & $\mathrm{v}$ & $\mathrm{v}$ & + & + or $\mathrm{V}$ \\
\hline Anaerobic growth & - & + & - & - \\
\hline Nitrate reduction & - & + & - & + \\
\hline Growth at $20 \% \mathrm{NaCl}$ & - & $\mathrm{w}$ & - & - \\
\hline $\begin{array}{l}\text { Optimum growth } \\
\text { temperature }\left({ }^{\circ} \mathrm{C}\right)\end{array}$ & 30 & $30-35$ & $12-23$ & 30 \\
\hline \multicolumn{5}{|l|}{ Growth at: } \\
\hline $5{ }^{\circ} \mathrm{C}$ & + & - & + & + \\
\hline \multicolumn{5}{|l|}{ Hydrolysis of: } \\
\hline Tween 80 & $\mathrm{w}$ & + & - & - \\
\hline \multicolumn{5}{|l|}{ Acid production from: } \\
\hline Cellobiose & $\mathrm{w}$ & - & - & + \\
\hline D-Galactose & + & + & - & - \\
\hline Mannitol & + & + & - & + \\
\hline D-Mannose & - & - & + & - \\
\hline Melezitose & + & + & $\mathrm{ND}$ & $\mathrm{w}$ \\
\hline Melibiose & - & + & - & + \\
\hline Raffinose & - & + & - & - \\
\hline D-Ribose & + & + & $\mathrm{ND}$ & - \\
\hline D-Xylose & - & - & + & - \\
\hline \multicolumn{5}{|l|}{ Enzyme activity (API ZYM)* } \\
\hline Esterase (C4) & + & + & - & - \\
\hline Esterase lipase (C8) & + & + & - & $\mathrm{w}$ \\
\hline $\begin{array}{l}\text { Naphthol-AS-BI- } \\
\text { phosphohydrolase }\end{array}$ & - & - & + & $\mathrm{w}$ \\
\hline$\beta$-Galactosidase & - & + & - & + \\
\hline$\alpha$-Glucosidase & - & + & - & - \\
\hline Predominant menaquinone(s) & MK-7, MK-8 & MK-7, MK-8 & MK-7 & MK-7, MK-8 \\
\hline Predominant fatty acid & anteiso- $\mathrm{C}_{15: 0}$ & iso- $\mathrm{C}_{15: 0}$ & anteiso- $\mathrm{C}_{15: 0}$ & anteiso- $\mathrm{C}_{15: 0}$ \\
\hline DNA G $+\mathrm{C}$ content $(\mathrm{mol} \%)$ & 42.9 & 44 & $39.3 \pm 0.5$ & 41.8 \\
\hline
\end{tabular}

${ }^{\star}$ Data for the type strains of reference species were from this study. 


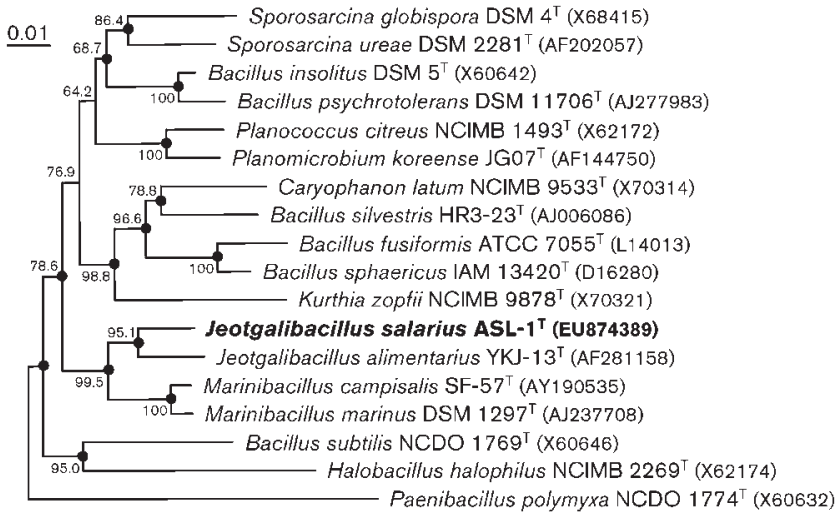

Fig. 1. Neighbour-joining phylogenetic tree based on $16 \mathrm{~S}$ rRNA gene sequences showing the positions of $J$. salarius $A S L-1^{\top}$ and some other related taxa. Bootstrap values (expressed as percentages of 1000 replications) of $>50 \%$ are shown at branch points. Filled circles indicate that the corresponding nodes were also recovered in the trees generated with the maximum-likelihood and maximum-parsimony algorithms. Paenibacillus polymyxa NCDO $1774^{\top}$ was used as an outgroup. Bar, 0.01 substitutions per nucleotide position.

similarity values $(96.5 \%)$ to the type strains of the two Marinibacillus species. It exhibited $16 \mathrm{~S}$ rRNA gene sequence similarity values less than $94.2 \%$ to other species used in the phylogenetic analysis.

The total hydrolysate of the peptidoglycan $(4 \mathrm{M} \mathrm{HCl}, 16 \mathrm{~h}$ at $100{ }^{\circ} \mathrm{C}$ ) of strain ASL- $1^{\mathrm{T}}$ contained the amino acids alanine, glutamic acid and lysine in the approximate ratio $1.6: 1.2: 1.0$. The partial hydrolysate contained the peptides L-Ala-D-Glu and L-Lys-D-Ala in addition to the amino acids. From these data, it was concluded that strain ASL- $1^{\mathrm{T}}$ has the peptidoglycan type A1 $\alpha$, L-Lys-direct, as described by Schleifer \& Kandler (1972). The predominant menaquinone detected in strain ASL- ${ }^{\mathrm{T}}$ was MK-7 (approx. $75 \%$ ); a significant amount of MK-8 (approx. $21 \%$ ) was also detected. The cellular fatty acid profile of strain ASL$1^{\mathrm{T}}$ is shown in Table 2, together with those of $J$. alimentarius $\mathrm{YKJ}-13^{\mathrm{T}}$ analysed in this study and two Marinibacillus species analysed previously (Yoon et al., $2001 \mathrm{~b}, 2004)$. Strain ASL- ${ }^{\mathrm{T}}$ had large amounts of branched and unsaturated fatty acids; the major components (each constituting $>10 \%$ of total fatty acids) were anteiso- $\mathrm{C}_{15: 0}, \mathrm{C}_{16: 1} \omega 7 c$ alcohol, anteiso- $\mathrm{C}_{17: 0}$, iso- $\mathrm{C}_{16: 0}$ and iso- $\mathrm{C}_{14: 0}$. This fatty acid profile of strain ASL- $1^{\mathrm{T}}$ was more similar to those of the type strains of two Marinibacillus species than to that of J. alimentarius YKJ$13^{\mathrm{T}}$, in that anteiso- $\mathrm{C}_{15: 0}$ was the predominant fatty acid (Tables 1 and 2). The DNA G + C content of strain ASL- $1^{\mathrm{T}}$ was $42.9 \mathrm{~mol} \%$.

The cell-wall peptidoglycan types (L-Lys-direct) of strain ASL $-1^{\mathrm{T}}$ and the genera Jeotgalibacillus and Marinibacillus were found to be identical (Yoon et al., 2001b, 2004). The
Table 2. Cellular fatty acid compositions (\%) of Jeotgalibacillus and Marinibacillus species

Strains: 1, ASL $^{-1}{ }^{\mathrm{T}}$ (J. salarius sp. nov.); 2, J. alimentarius $\mathrm{YKJ}-13^{\mathrm{T}}$ (data from this study); 3, M. marinus DSM $1297^{\mathrm{T}}$ (Yoon et al., 2001b); 4, M. campisalis SF- $57^{\mathrm{T}}$ (Yoon et al., 2004). Fatty acids that represent $<0.5 \%$ in all strains were omitted. - , Not detected.

\begin{tabular}{|c|c|c|c|c|}
\hline Fatty acid & 1 & 2 & 3 & 4 \\
\hline \multicolumn{5}{|c|}{ Straight-chain fatty acid } \\
\hline $\mathrm{C}_{14: 0}$ & 0.2 & 0.3 & - & 0.8 \\
\hline $\mathrm{C}_{15: 0}$ & 1.1 & 1.0 & - & 1.1 \\
\hline $\mathrm{C}_{16: 0}$ & 0.5 & 0.5 & 1.5 & 0.9 \\
\hline \multicolumn{5}{|c|}{ Unsaturated fatty acid } \\
\hline $\mathrm{C}_{16: 1} \omega 7 c$ alcohol & 12.6 & 6.7 & 2.6 & 12.3 \\
\hline $\mathrm{C}_{16: 1} \omega 11 c$ & 0.7 & 1.0 & - & 1.9 \\
\hline \multicolumn{5}{|c|}{ Branched fatty acid } \\
\hline iso- $\mathrm{C}_{14: 0}$ & 10.8 & 4.2 & 5.3 & 14.1 \\
\hline iso- $\mathrm{C}_{15: 0}$ & 9.4 & 46.3 & 22.2 & 2.5 \\
\hline anteiso- $\mathrm{C}_{15: 0}$ & 35.9 & 15.8 & 47.7 & 49.8 \\
\hline iso- $\mathrm{C}_{16: 0}$ & 12.0 & 6.3 & 5.1 & 5.2 \\
\hline iso- $\mathrm{C}_{17: 1} \omega 10 c$ & 0.3 & 2.3 & - & - \\
\hline iso- $\mathrm{C}_{17: 0}$ & 1.7 & 7.6 & 2.6 & - \\
\hline anteiso- $\mathrm{C}_{17: 0}$ & 12.2 & 5.8 & 10.7 & 7.4 \\
\hline \multicolumn{5}{|l|}{ Summed feature ${ }^{*}$} \\
\hline 4 & 2.4 & 1.9 & 2.3 & 3.9 \\
\hline
\end{tabular}

*Summed features represent groups of two or three fatty acids that cannot be separated by GLC with the MIDI system. Summed feature 4 contains iso- $\mathrm{C}_{17: 1}$ and/or anteiso- $\mathrm{C}_{17: 1}$.

genus Jeotgalibacillus was distinguished from the genus Marinibacillus, in which a significant amount of MK-8 is absent and the predominant fatty acid is anteiso- $\mathrm{C}_{15: 0}$ (Yoon et al., 2001b). However, the second Marinibacillus species, M. campisalis, was found to contain a significant amount of MK-8, although it formed a coherent cluster with M. marinus in the phylogentic tree based on $16 \mathrm{~S}$ rRNA gene sequences and contained anteiso- $\mathrm{C}_{15: 0}$ as the predominant fatty acid (Yoon et al., 2004). Strain ASL- $1^{\mathrm{T}}$ formed a coherent phylogenetic cluster with J. alimentarius and contained a significant amount of MK-8, but contained anteiso- $\mathrm{C}_{15: 0}$ as the predominant fatty acid, which is characteristic of the genus Marinibacillus. Because of the data given above, the taxonomic status of the genera Jeotgalibacillus and Marinibacillus might have to be reevaluated by considering the phylogenetic and chemotaxonomic data. The isoprenoid quinone profiles of strain ASL- $1^{\mathrm{T}}$ and members of the two genera were similar in that the predominant menaquinone was MK-7, although strain ASL- $1^{\mathrm{T}}$, J. alimentarius and $M$. campisalis contained significant amounts of MK-8 (approx. 20-35\%). The intrageneric differences in fatty acid profiles have been reported for members of some related genera (Yoon et al., 2001a; Hanada et al., 2002; Hua et al., 2007; Nam et al., 2008). Taking into account these data, it is likely to be more reasonable that the genera Jeotgalibacillus and 
Marinibacillus should be integrated into one genus, Jeotgalibacillus. Accordingly, it is proposed that M. marinus and M. campisalis be reclassified as members of the genus Jeotgalibacillus and strain ASL- ${ }^{\mathrm{T}}$ be considered as a member of the genus Jeotgalibacillus.

Strain ASL- ${ }^{\mathrm{T}}$ exhibited a mean DNA-DNA relatedness value of $13 \%$ with respect to J. alimentarius YKJ-13 ${ }^{\mathrm{T}}$. Strain ASL $-1^{\mathrm{T}}$ could be distinguished from J. alimentarius and the two Marinibacillus species by differences in several phenotypic characteristics, including spore shape, anaerobic growth, nitrate reduction, hydrolysis of and acid production from several substrates, activity of some enzymes and susceptibility to antibiotics (Table 1). The phylogenetic and genetic distinctiveness and the differential phenotypic properties of strain ASL- ${ }^{\mathrm{T}}$ are sufficient to categorize it as a member of a species that is separate from J. alimentarius and the two Marinibacillus species (Wayne et al., 1987; Stackebrandt \& Goebel, 1994). On the basis of the data presented, strain ASL- $1^{\mathrm{T}}$ represents a novel species of the genus Jeotgalibacillus, for which the name Jeotgalibacillus salarius sp. nov. is proposed.

\section{Description of Jeotgalibacillus salarius sp. nov.}

Jeotgalibacillus salarius (sa.la'ri.us. L. masc. adj. salarius of salt).

Cells are Gram-variable and rod-shaped $(0.4-0.7 \times 1.3$ $8.5 \mu \mathrm{m})$. Cells longer than $10.0 \mu \mathrm{m}$ occasionally occur. Subterminal ellipsoidal endospores are observed in slightly swollen sporangia. Motile by means of peritrichous flagella. Colonies on MA are circular to irregular, raised, glistening, smooth, light-yellow in colour and $2.0-3.0 \mathrm{~mm}$ in diameter after 2 days incubation at $30{ }^{\circ} \mathrm{C}$. The optimal growth temperature is $30{ }^{\circ} \mathrm{C}$; growth occurs at 4 and $40{ }^{\circ} \mathrm{C}$, but not at $45{ }^{\circ} \mathrm{C}$. The optimal $\mathrm{pH}$ for growth is between 7.0 and 8.0; growth occurs at $\mathrm{pH} 6.0$, but not at $\mathrm{pH} 5.5$. Optimal growth occurs in the presence of $2 \%(\mathrm{w} / \mathrm{v}) \mathrm{NaCl}$; growth occurs at $0-18 \%(\mathrm{w} / \mathrm{v}) \mathrm{NaCl} . \mathrm{Mg}^{2+}$ ions are required for growth. Anaerobic growth does not occur on MA or on MA supplemented with nitrate. Catalase- and oxidase-positive. Nitrate reduction is negative. Aesculin and casein are hydrolysed and Tween 80 is weakly hydrolysed, but gelatin, starch, hypoxanthine, xanthine, tyrosine and urea are not. Acid is produced from Dfructose, D-galactose, D-glucose, maltose, D-mannitol, melezitose, D-ribose, sucrose and trehalose and weakly produced from cellobiose, but not from L-arabinose, myoinositol, lactose, D-mannose, melibiose, L-rhamnose, raffinose, D-sorbitol or D-xylose. Esterase (C4) and esterase lipase (C8) are present, but alkaline phosphatase, lipase (C14), leucine arylamidase, valine arylamidase, cystine arylamidase, trypsin, $\alpha$-chymotrypsin, acid phosphatase, naphthol-AS-BI-phosphohydrolase, $\alpha$-galactosidase, $\beta$ galactosidase, $\beta$-glucuronidase, $\alpha$-glucosidase, $\beta$-glucosidase, $N$-acetyl- $\beta$-glucosaminidase, $\alpha$-mannosidase and $\alpha$ fucosidase are absent. Susceptible to ampicillin, carbenicillin, cephalothin, chloramphenicol, gentamicin, kanamy- cin, lincomycin, neomycin, novobiocin, oleandomycin, penicillin G, streptomycin and tetracycline, but not to polymyxin B. The peptidoglycan type is A $1 \alpha$ (L-Lys-direct). The predominant menaquinone is MK-7; a significant amount of MK-8 is also present. Major fatty acids ( $>10 \%$ of total fatty acids) are anteiso- $\mathrm{C}_{15: 0}, \mathrm{C}_{16: 1} \omega 7 \mathrm{c}$ alcohol, anteiso- $\mathrm{C}_{17: 0}$, iso- $\mathrm{C}_{16: 0}$ and iso- $\mathrm{C}_{14: 0}$. The DNA $\mathrm{G}+\mathrm{C}$ content of the type strain is $42.9 \mathrm{~mol} \%$ (determined by HPLC).

The type strain, ASL $-1^{\mathrm{T}}\left(=\mathrm{KCTC} 13257^{\mathrm{T}}=\mathrm{CCUG} 56751^{\mathrm{T}}\right)$, was isolated from sediment of a marine saltern located on the coast of the Yellow Sea, Korea.

\section{Description of Jeotgalibacillus marinus (Rüger and Richter 1979) comb. nov.}

Jeotgalibacillus marinus (ma.ri'nus. L. masc. adj. marinus of the sea, marine).

Basonym: Bacillus globisporus subsp. marinus Rüger and Richter 1979 (Approved Lists 1980).

Marinibacillus marinus (Rüger and Richter 1979) Yoon et al. 2001 is another homotypic synonym.

The description is the same as those given by Rüger \& Richter (1979), Rüger (1983), Rüger et al. (2000) and Yoon et al. (2001b). Additional characteristics for the type strain determined in this study are as follows. Naphthol-AS-BIphosphohydrolase is present, but alkaline phosphatase, esterase (C4), esterase lipase (C8), lipase (C14), leucine arylamidase, valine arylamidase, cystine arylamidase, trypsin, $\alpha$-chymotrypsin, acid phosphatase, $\alpha$-galactosidase, $\beta$ galactosidase, $\beta$-glucuronidase, $\alpha$-glucosidase, $\beta$-glucosidase, $N$-acetyl- $\beta$-glucosaminidase, $\alpha$-mannosidase and $\alpha$ fucosidase are absent. Susceptible to carbenicillin, cephalothin, chloramphenicol, gentamicin, neomycin, oleandomycin and penicillin G, but not to ampicillin, kanamycin, lincomycin, novobiocin, polymyxin B, streptomycin or tetracycline.

The type strain is strain $581^{\mathrm{T}}\left(=\mathrm{DSM} 1297^{\mathrm{T}}=\right.$ ATCC $29841^{\mathrm{T}}=$ CCUG $28884^{\mathrm{T}}=$ CIP $103308^{\mathrm{T}}=$ LMG $6930^{\mathrm{T}}$ ).

\section{Description of Jeotgalibacillus campisalis Yoon et al. 2004 comb. nov.}

Jeotgalibacillus campisalis (cam.pi.sa'lis. L. n. campus field; L. gen. n. salis of salt; N.L. gen. n. campisalis of the field of salt).

Basonym: Marinibacillus campisalis Yoon et al. 2004.

The description is the same as that given by Yoon et al. (2004). Additional characteristics determined in this study are as follows. $\beta$-Galactosidase is present and esterase lipase (C8) and naphthol-AS-BI-phosphohydrolase are weakly present, but alkaline phosphatase, esterase (C4), lipase (C14), leucine arylamidase, valine arylamidase, cystine arylamidase, trypsin, $\alpha$-chymotrypsin, acid phosphatase, $\alpha$-galactosidase, $\beta$-glucuronidase, $\alpha$-glucosidase, $\beta$-glucosi- 
dase, $N$-acetyl- $\beta$-glucosaminidase, $\alpha$-mannosidase and $\alpha$ fucosidase are absent. Susceptible to ampicillin, carbenicillin, cephalothin, chloramphenicol, gentamicin, kanamycin, neomycin, oleandomycin, penicillin $G$ and streptomycin, but not to lincomycin, novobiocin, polymyxin B or tetracycline.

The type strain is strain SF- $57^{\mathrm{T}}\left(=\mathrm{KCCM} 41644^{\mathrm{T}}=\mathrm{JCM}\right.$ $11810^{\mathrm{T}}$.

\section{Acknowledgements}

This work was supported by the 21C Frontier program of Microbial Genomics and Applications (grant MG05-0401-2-0) from the Ministry of Science and Technology (MOST) of the Republic of Korea.

\section{References}

Bruns, A., Rohde, M. \& Berthe-Corti, L. (2001). Muricauda ruestringensis gen. nov., sp. nov., a facultatively anaerobic, appendaged bacterium from German North Sea intertidal sediment. Int $J$ Syst Evol Microbiol 51, 1997-2006.

Cowan, S. T. \& Steel, K. J. (1965). Manual for the identification of medical bacteria. London: Cambridge University Press.

Ezaki, T., Hashimoto, Y. \& Yabuuchi, E. (1989). Fluorometric deoxyribonucleic acid-deoxyribonucleic acid hybridization in microdilution wells as an alternative to membrane filter hybridization in which radioisotopes are used to determine genetic relatedness among bacterial strains. Int J Syst Bacteriol 39, 224-229.

Groth, I., Schumann, P., Weiss, N., Martin, K. \& Rainey, F. A. (1996). Agrococcus jenensis gen. nov., sp. nov., a new genus of actinomycetes with diaminobutyric acid in the cell wall. Int J Syst Bacteriol 46, 234239 .

Hanada, S., Liu, W. T., Shintani, T., Kamagata, Y. \& Nakamura, K. (2002). Tetrasphaera elongata sp. nov., a polyphosphate-accumulating bacterium isolated from activated sludge. Int J Syst Evol Microbiol 52, 883-887.

Hua, N.-P., Kanekiyo, A., Fujikura, K., Yasuda, H. \& Naganuma, T. (2007). Halobacillus profundi sp. nov. and Halobacillus kuroshimensis sp. nov., moderately halophilic bacteria isolated from a deep-sea methane cold seep. Int J Syst Evol Microbiol 57, 1243-1249.

Komagata, K. \& Suzuki, K. (1987). Lipids and cell-wall analysis in bacterial systematics. Methods Microbiol 19, 161-207.

Lányí, B. (1987). Classical and rapid identification methods for medically important bacteria. Methods Microbiol 19, 1-67.

Leifson, E. (1963). Determination of carbohydrate metabolism of marine bacteria. J Bacteriol 85, 1183-1184.

MacKenzie, S. L. (1987). Gas chromatographic analysis of amino acids as the $N$-heptafluorobutyryl isobutyl esters. J Assoc Off Anal Chem 70, 151-160.
Nam, J.-H., Bae, W. \& Lee, D.-H. (2008). Oceanobacillus caeni sp. nov., isolated from a Bacillus-dominated wastewater treatment system in Korea. Int J Syst Evol Microbiol 58, 1109-1113.

Rüger, H.-J. (1983). Differentiation of Bacillus globisporus, Bacillus marinus comb. nov., Bacillus aminovorans, and Bacillus insolitus. Int $J$ Syst Bacteriol 33, 157-161.

Rüger, H.-J. \& Richter, G. (1979). Bacillus globisporus subsp. marinus subsp. nov. Int J Syst Bacteriol 29, 196-203.

Rüger, H.-J., Fritze, D. \& Spröer, C. (2000). New psychrophilic and psychrotolerant Bacillus marinus strains from tropical and polar deepsea sediments and emended description of the species. Int J Syst Evol Microbiol 50, 1305-1313.

Sasser, M. (1990). Identification of bacteria by gas chromatography of cellular fatty acids, Technical Note no. 1. Newark, DE: MIDI Inc.

Schleifer, K. H. \& Kandler, O. (1972). Peptidoglycan types of bacterial cell walls and their taxonomic implications. Bacteriol Rev 36, 407-477.

Stackebrandt, E. \& Goebel, B. M. (1994). Taxonomic note: a place for DNA-DNA reassociation and $16 \mathrm{~S}$ rRNA sequence analysis in the present species definition in bacteriology. Int J Syst Bacteriol 44, 846849.

Tamaoka, J. \& Komagata, K. (1984). Determination of DNA base composition by reversed-phase high-performance liquid chromatography. FEMS Microbiol Lett 25, 125-128.

Wayne, L. G., Brenner, D. J., Colwell, R. R., Grimont, P. A. D., Kandler, O., Krichevsky, M. I., Moore, L. H., Moore, W. E. C., Murray, R. G. E. \& other authors (1987). International Committee on Systematic Bacteriology. Report of the ad hoc committee on reconciliation of approaches to bacterial systematics. Int J Syst Bacteriol 37, 463-464.

Yoon, J.-H., Kim, H., Kim, S.-B., Kim, H.-J., Kim, W. Y., Lee, S. T., Goodfellow, M. \& Park, Y.-H. (1996). Identification of Saccharomonospora strains by the use of genomic DNA fragments and rRNA gene probes. Int J Syst Bacteriol 46, 502-505.

Yoon, J.-H., Lee, S. T. \& Park, Y.-H. (1998). Inter- and intraspecific phylogenetic analysis of the genus Nocardioides and related taxa based on 16S rRNA gene sequences. Int J Syst Bacteriol 48, 187-194.

Yoon, J.-H., Kang, S.-S., Lee, K.-C., Kho, Y. H., Kang, K. H. \& Park, Y.-H. (2001a). Planomicrobium koreense gen. nov., sp. nov., a bacterium isolated from the Korean traditional fermented seafood jeotgal, and transfer of Planococcus okeanokoites (Nakagawa et al. 1996) and Planococcus momeekinii (Junge et al. 1998) to the genus Planomicrobium. Int J Syst Evol Microbiol 51, 1511-1520.

Yoon, J.-H., Weiss, N., Lee, K.-C., Lee, I.-S., Kang, K. H. \& Park, Y.-H. (2001b). Jeotgalibacillus alimentarius gen. nov., sp. nov., a novel bacterium isolated from jeotgal with L-lysine in the cell wall, and reclassification of Bacillus marinus Rüger 1983 as Marinibacillus marinus gen. nov., comb. nov. Int J Syst Evol Microbiol 51, 2087-2093.

Yoon, J.-H., Kang, K. H. \& Park, Y.-H. (2003). Psychrobacter jeotgali sp. nov., isolated from jeotgal, a traditional Korean fermented seafood. Int J Syst Evol Microbiol 53, 449-454.

Yoon, J.-H., Kim, I.-G., Schumann, P., Oh, T.-K. \& Park, Y.-H. (2004). Marinibacillus campisalis sp. nov., a moderate halophile isolated from a marine solar saltern in Korea, with emended description of the genus Marinibacillus. Int J Syst Evol Microbiol 54, 1317-1321. 